\title{
Total Factor Energy Productivity and Efficiency Changes of the Gher (Prawn-Carp-Rice) Farming System in Bangladesh: A Stochastic Input Distance Function Approach
}

\author{
Sanzidur Rahman ${ }^{1, *(D)}$ and Basanta Kumar Barmon ${ }^{2}$ (D) \\ 1 School of Geography, Earth and Environmental Sciences, University of Plymouth, Drake Circus, \\ Plymouth PL4 8AA, UK \\ 2 Department of Economics, East West University, A/2, Jahurul Islam City, Aftabnagar, \\ Dhaka 1212, Bangladesh; bkbarmon@ewubd.edu \\ * Correspondence: srahman@plymouth.ac.uk; Tel.: +44-1752-585-911; Fax: +44-1752-584-710
}

Received: 22 November 2018; Accepted: 11 December 2018; Published: 13 December 2018

\begin{abstract}
This paper measures energy performance, Total Factor Energy Productivity (TFEP), technical change (TC) and energy efficiency change (EEC) of the gher (prawn-carp-rice) farming system using a unique panel data of 90 farmers covering a 14 year period (2002-2015) from southwest Bangladesh by employing a stochastic input distance function approach. Results reveal that all inputs contribute significantly to energy productivity of the gher farming system with male labor energy input being the major contributor followed by energy from machineries, seeds and chemicals. Energy performance of the High Yielding Variety (HYV) rice enterprise is highly efficient whereas the prawn enterprise is highly energy inefficient. Furthermore, energy performance of the HYV rice enterprise improved significantly over time. Significant competition exists between HYV rice and prawn enterprises as well as prawn and carp enterprises. Experience and education significantly improve energy efficiency whereas gher area and household size significantly reduces it. TFEP grew at the rate of $2.56 \%$ per annum (p.a.) solely powered by technical progress at the rate of $2.57 \%$ p.a. Gher system can be sustained in the long-run driven by technical progress and improvements in energy productivity of the HYV rice enterprise. Policy implications include investments in $R \& D$ and education targeted at the gher farmers.
\end{abstract}

Keywords: Total Factor Energy Productivity; technical change; energy efficiency change; Gher farming system; panel data

\section{Introduction}

Energy from fossil fuel and renewable sources are a vital resource for human development and agriculture. Globally 473 quads ( 1 quad $=10^{15} \mathrm{BTU}=1.05 \times 10^{18}$ Joules [1]) of fossil fuel and renewable energy used every year [2], which is mainly due to population growth, urbanization and high level of resource consumption rates [1]. Future demand for energy is projected to double every 32 years in response to a doubling of population $\backslash$ every 50-60 years [2,3]. Developing economies with a high rate of population growth are increasingly using fossil fuel in agriculture to meet growing demand for food and fiber [1]. The global production of inorganic fertilizers, a vital input necessary for modern agriculture, has declined by $22 \%$, and due to limited amount of fossil fuel, its availability is likely to decline further in the future [1].

Cereals (rice, wheat and corn) make up about $80 \%$ of the global food production and the remaining comes from soybeans, roots and tubers (e.g., cassava, potato and sweet potatoes) [4]. 
However, energy composition varies drastically between highly mechanized-high productivity system and high labor-low productivity system for the same crop. For example, energy input-output ratio of producing corn per ha is 1:4.11 in USA and 1:1.08 in Indonesia. Consequently, productivity of corn in USA is 5.46 times higher, estimated at $9400 \mathrm{~kg} / \mathrm{ha}$, as compared to only $1721 \mathrm{~kg} / \mathrm{ha}$ in Indonesia [1]. However, such high-energy consumption based food production system is not going to be sustainable. Worldwide cereal produced per capita has declined since 1984 and it seems that food supply is unlikely to be sustained in the future [1]. Therefore, it is important to explore production technologies, which are not only capable of producing more food and profitable, but also energy efficient.

The agricultural economy of Bangladesh, dominated by cereal crop production, has also experienced a dramatic rise in the energy consumption over time owing to diffusion of the Green Revolution technology. For example, energy intensity in the agricultural sector in Bangladesh has increased from 1.78 in 2000 to 11.31 in 2008 [5], thereby adding substantial pressure on the existing acute shortage of energy in the economy [6]. Rahman and Kazal [7] noted that energy use increases by $0.14 \%$ for every one percent increase in cereal output, at the farm level in Bangladesh. The government of Bangladesh has been trying to enhance other sources of food production since 1990s, which can generate high income for farmers and export earnings for the economy, e.g., fisheries and aquaculture. Fish alone accounts for $60 \%$ of daily protein intake and about $11 \%$ of the total population of Bangladesh are engaged in the fisheries sector either on a full-time or part-time basis [8].

In recent years, freshwater prawn farming has become a major contributor to global aquaculture in terms of quantity and value of production [9]. About $571,152 \mathrm{t}$ of freshwater prawns were produced worldwide in 2013 and the sector is valued at USD 3 billion/year [10]. The integrated culture of rice and prawn in inundated rice fields is a traditional practice in many Southeast Asian countries [11,12]. During the last two decades, integrated prawn-fish-rice farming has expanded in Asia, mainly due to export potential of freshwater prawn (Macrobrachium rosenbergii) and its high market value $[13,14]$.

Freshwater prawn cultivation in rice fields started in Bangladesh during the 1970s, gained momentum from the mid-1980s due to favorable agro-climatic conditions prevailing in the coastal regions $[3,15]$. The total area dedicated to prawn cultivation in Bangladesh was estimated at 275,509 ha in 2015/16 producing 239,798 t of shrimp/prawn with a yield level of $870 \mathrm{~kg} / \mathrm{ha}$ [8]. Approximately 1.15 million farmers are involved in prawn and shrimp production, of which 315,000 farmers $(27 \%)$ are employed in prawn culture [16]. Prawns and shrimps are considered as the 2nd largest export industry after garments. Bangladesh exported 40,728 $t$ of prawns and shrimps valued at USD 459 million in 2015/16 [8]. Although the country mainly practices low-intensity prawn farming system, it has great potential. For example, Ahmed and Flaherty [17] noted that if the low-intensive prawn farming system could be expanded by only $50 \%$ of the potential area of 55,000 ha in the southwest region, the country could earn an additional USD 70 million of revenue annually.

About $60-70 \%$ of the freshwater prawn farming in the southwest region of Bangladesh is conducted within a gher farming system that incorporates joint operation of three enterprises: freshwater prawn, carp and HYV Boro (dry winter season) rice [15]. The locally used term gher refers to the modification of rice fields by building higher dikes around the field and digging a deep canal inside the periphery to preserve water during the dry season [18]. Gher farming is a unique indigenous innovation, which is suitable for the cultivation of prawn, fish, rice and dike crops. The widespread development of the gher farming system in coastal regions of Bangladesh was likened to a 'blue revolution' [19], which in turn refers to the rise of aquaculture as an important agricultural activity [20].

A unique feature of the gher farming system is the use of a wide variety of inputs, particularly diverse feed ingredients, some of which are sourced naturally. A number of papers on gher farming exist, but those are mainly focused on its management aspects and/or food security $[13,17,21]$ and profitability and productivity of the system [15,22]. Only Rahman and Barmon [6] examined the energy productivity and efficiency of the gher farming system based on a cross-section data for the crop year 2006, which concluded that the system is sustainable in terms of energy use. 
However, there is no literature that has explored whether the system is performing well and is sustainable over time when evaluated in terms of energy use. This is because a production system can be considered sustainable over the long term if any net increase in energy output surpasses the net increase in energy input levels [6]. Furthermore, the composition of energy used, i.e., the balance between renewable and fossil fuel based sources, is important to examine since the latter is becoming scarce over time [23]. This is particularly important for the gher farming system since it is a highly input intensive production technology. Marques et al. [24] noted that integrating freshwater prawn farming with other farming activities has considerable potential as a means of increasing food production in a sustainable fashion.

Sustainability in agriculture is a complex concept with several dimensions to consider and its measurement is quite challenging $[25,26]$. Although several indicators were developed to measure agricultural sustainability, they do not cover all dimensions [26]. For example, Sabiha et al. [25] developed a composite indicator based approach using 17 indicators to capture multi-dimensional aspects of agriculture to measure only environmental sustainability. In this study, we applied a consistent method where all inputs and outputs of an agricultural production system are measured in energy units and examined its performance over time, which enabled us to incorporate the notion of the dynamics of sustainability as well.

Given this backdrop, sustainability of the gher farming system was evaluated in terms of energy use by examining various measures of energy performance. The specific aims of this study are to: (a) examine trends in basic energy performance measures of the gher farming system over time; (b) identify the drivers of energy productivity of the gher farming system; (c) identify the determinants of technical energy efficiency; and (d) most importantly, examine changes in Total Factor Energy Productivity (TFEP) and its key components: technical change (TC) and technical energy efficiency change (EEC) over time.

The specific contributions of our study to the existing literature is mainly on the methodology to compute TFEP, TC and EEC. Conventionally, TFEP and/or total factor energy efficiency (TFEE) analysis were conducted at the macro-level or regional level for an economy as a whole, where the output is specified as the Gross Domestic Product (GDP) and labor/employment, energy consumption and capital stock are used as inputs. The main approach applied is the non-parametric Data Envelopment Analysis (DEA) [27-30]. Although improvements were made in terms of measuring TFEP/TFEE using multi-stage Slack Based DEA model [27] and improved calculations of TFEE using no-output growth or output growth models [28], the basic approach suffers from two limitations. One is the well-known limitation of non-parametric DEA approach, i.e., all statistical noises and measurement errors are included as inefficiency, implying that energy efficiency scores derived may be biased. Second, the input and output variables used in the analysis are not measured in energy units. Except the energy consumption variable, all other variables are measured in different units and are subject to issues of aggregation (e.g., GDP is an aggregate measure) and/or construction procedures, e.g., construction of capital stock is open for interpretation because the correct value of this variable over time for an economy at a disaggregated scale can hardly be obtained. Although, units of measure do not pose any serious problem in DEA approach, it is desirable to specify variables that are not subject to the limitation of aggregation and/or construction problems. Such varied unit of measurement of variables necessitated the calculation of TFEE by making adjustments $[27,29,31,32]$. Therefore, all these issues can lead to biased measures of TFEE and/or TFEP consequently leading to biased policy prescriptions. We use the well-established concept of Total Factor Productivity (TFP), which is based on the theoretical foundation of underlying production function. Furthermore, we apply the parametric method for the analysis, specifically, stochastic input distance function approach, which can conveniently incorporate the specification of multi-output multi-input production technology and, therefore, do not require aggregation of outputs or inputs into single indices. This approach can separate statistical noise and measurement errors from inefficiency as well. Furthermore, we consistently measure all outputs and inputs in energy equivalent units actually 
used in the production process, implying that no proxy variables measured in different units are used. Therefore, the resulting TFEP index is of the Malmquist type index and the two associated components are TC and EEC (equivalent to TFEE), requiring no adjustments to obtain TFEE as done by the previous studies. The other contributions of our study to the existing literature are as follows. We provide information on the changes in common partial measures of energy performance over time of this unique farming system, which is relatively more robust than the conclusions drawn from cross-sectional studies undertaken at a point of time [6]. We also identify significant drivers of energy productivity and technical energy efficiency and other performance measures, such as, scale economy and output jointness or complementarity amongst enterprises. Furthermore, the computation of TFEP, TC and EEC indices of the gher farming system will provide information on whether there is net growth in productivity of this farming system and whether it can be sustained over time when evaluated in terms of energy use. This is because TFP indices capture the effect of improvements in technology in the form of R\&D [33]. Furthermore, higher TFEP is desirable because it implies higher output from the application of technology, better utilization of resources and leads to a reduction in poverty in rural areas [34]. The results will also be useful for policy makers and relevant stakeholders aimed at enhancing food production and increasing income of the farmers without compromising sustainability of the system.

\section{Materials and Methods}

\subsection{Data and the Study Area}

This study is based on a unique set of farm-level panel data covering a 14-year period (2002-2015) collected from Bilpabla village, located in southwest Bangladesh. The village was purposively selected because farmers in this village have been engaged in the gher farming system for a long time. Also, Bilpabla village can be considered a typical village of the Dumuria sub-district of Khulna District. The first year of data collection took place in 2002. Bilpabla village has 410 farm households of which 90 farmers ( $22 \%$ of total population), whose major income source is gher farming, were selected using a simple random sampling procedure for the survey. The first round of data was collected over a six-month period (i.e., November 2001-April 2002). Since then, the same set of 90 farmers was surveyed every year until 2015, therefore providing a unique cohort of 90 famers over a 14-year period bringing the total sample size to 1260 observations. The dataset thus forms a strongly balanced panel of 90 farmers covering a 14-year period and provides a unique opportunity to examine the dynamics of productivity and efficiency changes of the gher farming system at the producer level. The questionnaire used in the survey contained three sections. Section A contained information on socio-economic conditions, (e.g., experience/age of the farmer, education, family size, farm size etc.). Section B covered detailed information on the quantity and value of inputs and outputs of HYV rice production (e.g., seedlings, inorganic fertilizers organic fertilizer, family and hired male and female labor, irrigation, pesticides, HYV rice output and straw as by-product). Section C covered detailed information on the quantity and value of inputs and outputs of prawn-carp production (e.g., fingerlings, feeds, family and hired male and female labor, chemicals and prawn and carp outputs). Overall, 20 questions were used in a tabular format to collect full information on the gher farming system. The questionnaire was pretested prior to the survey and locally recruited enumerators were used for data collection.

\subsection{Analytical Framework}

The analytical framework include: (a) computing basic partial measures of energy performance, such as, energy productivity, energy use efficiency and net energy balance [6,7,35]; and (b) an application of the stochastic input-distance function approach to identify drivers of energy productivity and efficiency as well as to compute indices of TFEP, TC and EEC. 


\subsubsection{Basic Energy Measures of Input-Output Ratios}

Common partial measures of energy input and output were computed for each enterprise of the gher farming system for each year to examine movement in these measures over time. These are: $[6,7,35,36]$ :

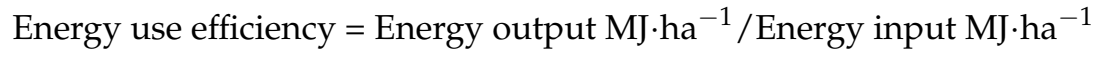

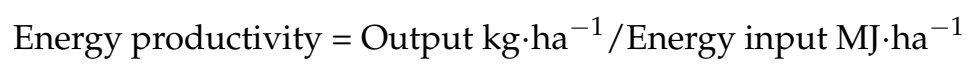

$$
\begin{aligned}
& \text { Specific energy = Energy input MJ } \cdot \mathrm{ha}^{-1} / \mathrm{Output}^{\mathrm{t}} \cdot \mathrm{ha}^{-1} \\
& \text { Net energy }=\text { Energy output MJ.ha }{ }^{-1}-\text { Energy Input MJ.ha }{ }^{-1}
\end{aligned}
$$

Since data contains a very detailed breakdown of all outputs and inputs of each enterprise of the gher farming system, we were able to conduct an ex-post analysis of the system by using standard energy coefficients from published literature to convert all physical inputs and outputs into energy units $[6,7,35,37]$. For some inputs and outputs, whose energy equivalents are not commonly available, we have calculated those values using the methods utilized by Rahman and Barmon [6]. Table 1 presents energy coefficients used in this study.

\begin{tabular}{|c|c|c|c|}
\hline Particulars & Unit & $\begin{array}{l}\text { Energy Equivalent } \\
\left(\mathrm{MJ} \cdot \text { unit }^{-1}\right)\end{array}$ & References \\
\hline \multicolumn{4}{|l|}{ A. Prawn and carp enterprise } \\
\hline \multicolumn{4}{|l|}{ Inputs } \\
\hline Prawn fingerling & $\mathrm{kg}$ & 4.40 & [6] \\
\hline Fish fingerling & $\mathrm{kg}$ & 4.52 & [38] \\
\hline Egg & $\mathrm{kg}$ & 6.20 & [38] \\
\hline Vermicelli & $\mathrm{kg}$ & 5.59 & [38] \\
\hline Fish meal & $\mathrm{kg}$ & 12.14 & [6] \\
\hline Meat of snail & $\mathrm{kg}$ & 3.37 & [6] \\
\hline Oilcake & $\mathrm{kg}$ & 14.40 & {$[6,38]$} \\
\hline Broken rice & $\mathrm{kg}$ & 15.28 & [38] \\
\hline Wheat bran & $\mathrm{kg}$ & 9.02 & {$[6,37]$} \\
\hline Flattened rice & $\mathrm{kg}$ & 14.40 & [38] \\
\hline Pulses & $\mathrm{kg}$ & 14.11 & [38] \\
\hline Male labor & hour & 1.96 & [37] \\
\hline Female labor & hour & 1.57 & [37] \\
\hline \multicolumn{4}{|l|}{ Outputs } \\
\hline Prawn & $\mathrm{kg}$ & 4.40 & [6] \\
\hline Fish & $\mathrm{kg}$ & 4.61 & [38] \\
\hline \multicolumn{4}{|l|}{ B. HYV rice enterprise: } \\
\hline \multicolumn{4}{|l|}{ Inputs } \\
\hline Rice seed & $\mathrm{kg}$ & 15.28 & [38] \\
\hline Power tiller (land preparation) & litre & 62.20 & [6] \\
\hline Irrigation (diesel) & litre & 56.31 & [35] \\
\hline Pesticides & litre & 120.00 & [35] \\
\hline Nitrogen $(\mathrm{N})$ & $\mathrm{kg}$ & 66.14 & [35] \\
\hline $\mathrm{P}_{2} \mathrm{O}_{5}$ & $\mathrm{~kg}$ & 12.44 & [35] \\
\hline $\mathrm{K}_{2} \mathrm{O}$ & $\mathrm{kg}$ & 11.15 & [35] \\
\hline Sulphur (S) & $\mathrm{kg}$ & 1.12 & [35] \\
\hline
\end{tabular}

Table 1. Energy coefficients for inputs and outputs of the gher farming system. 
Table 1. Cont.

\begin{tabular}{cccc}
\hline Particulars & Unit & $\begin{array}{c}\text { Energy Equivalent } \\
\text { (MJ· unit }{ }^{-1} \text { ) }\end{array}$ & References \\
\hline Outputs & & & \\
\hline Rice & $\mathrm{kg}$ & 15.28 & {$[38]$} \\
Rice Bran & $\mathrm{kg}$ & 13.23 & {$[38]$} \\
Straw & $\mathrm{kg}$ & 2.25 & {$[6,38]$} \\
\hline
\end{tabular}

Note: IFPRI refers to standard conversion used by the Food Consumption and Nutrition Division of IFPRI to compute calorific and dietary requirements for Bangladesh (personal communication).

\subsubsection{The Stochastic Input Distance Function}

The gher farming system represents a multi-output, multi-input production technology, which can be analyzed with a distance function using either parametric or non-parametric approach. We have specifically adopted the stochastic input-distance function approach because it does not require the assumption of separability of inputs and outputs [39], can provide econometric estimation of the drivers of energy productivity and efficiency and can be used to compute TFEP, TC and EEC indices over time.

The production technology of the gher farm is defined by using the input set, $L(y)$, representing the set of all input vectors, $x \in R_{+}^{K}$, producing the output vector $y \in R_{+}^{M}$ :

$$
L^{t}(y)=\left\{x \in R_{+}^{K}: x \text { can produce } y\right\}
$$

Then the input-distance function is defined on the input set, $L(y)$, as

$$
D_{I}^{t}(x, y)=\max \left\{\rho:(x / \rho) \in L^{t}(y)\right\}
$$

where $D_{I}^{t}(x, y)$ is non-decreasing, positively linearly homogenous and concave in $x$, and increasing in $y$. The distance function, $D_{I}^{t}(x, y)$, takes a value $\geq 1$ if the input vector, $x$, is in the feasible input set, $L^{t}(y)\left[D_{I}^{t}(x, y) \geq 1\right.$ if $\left.x \in L^{t}(y)\right] . D_{I}^{t}(x, y)=1$ if $x$ is situated on the inner boundary of the input set. The input distance function is interpreted as the multi-input input-requirement function and provides a measure of technical efficiency because its reciprocal is the Farrell's technical efficiency index [40,41].

The input distance function is homogenous of degree one in inputs [42]. The duality between the cost function and the input distance function can be usefully interpreted from the empirical estimate of the model [40]:

$$
C^{t}(w, y)=\min _{x}\left\{w x: D_{I}^{t}(x, y) \geq 1\right\}
$$

where $w$ is the vector of input prices, and the derivatives of the input distance function can be easily related to that of cost function. For example, the derivative with respect to input level $x_{k}$, is given by:

$$
\frac{\partial D_{I}^{t}\left(x^{* t}(w, y), y\right)}{\partial x_{k}}=\frac{w_{k}}{C^{t}(w, y)}=r_{k}^{* t}(x, y)
$$

Equation (8) shows that the derivative of the input distance function with respect to $k$ is equivalent to cost deflated shadow price of the input $r_{k}^{* t}>0$. Furthermore, the log derivative of the input distance function with respect to input $k$ is equivalent to the cost share of that input $S_{k}^{t}$ :

$$
\varepsilon_{D_{I}^{t}, x_{k}}=\frac{\partial \ln D_{I}^{t}}{\partial \ln x_{k}}=\frac{w_{k} x_{k}^{* t}(w, y)}{C^{t}(w, y)}=S_{k}^{t}
$$

This elasticity measure shows the relative importance of that input used in production [40]. 
Similarly, with the application of envelope theorem to Equation (7), the log derivative of the input distance function with respect to an output $y$ is equivalent to the negative of the cost elasticity of that output [40]:

$$
\varepsilon_{D_{I}^{t}, y_{m}}=\frac{\partial \ln D_{I}^{t}\left(x^{* t}(w, y), y\right)}{\partial \ln y_{m}}=-\frac{\partial \ln C^{t}(w, y)}{\partial \ln y_{m}}
$$

The value is expected to be negative for all outputs and the magnitude reflects the relative importance of each output.

The distance function can also be used to obtain information on the technological process over time as follows [40]:

$$
D_{I}^{t}(x, y)=D_{I}(x, y, t)
$$

and with the application of the envelope theorem to Equation (7), the elasticity of the input distance function with respect to time $t$ is equivalent to the responsiveness of cost reduction and, therefore, provides a measure of the rate of technical change. The positive value of this elasticity represents technical progress and the negative value as technical regress [40].

The input distance function is also capable of providing information on other performance measures, such as scale economy, input-output substitutability, output jointness or complementarity. For example, the combined first-order input elasticities represent scale economies, which shows the level of productivity increase in response to an increase in input growth. The individual input elasticity summarizes the input expansion required to increase output by one percent. The second-order elasticities provide information on the production complementarities, which reflect economic impacts arising from output jointness. That is if the output relationships are complementary, than an increase in one output increases the contribution of other outputs, therefore, enhancing performance of the system (for details of derivations of these measures from the distance function, please see $[6,7,41,43]$.

\subsubsection{The Empirical Model}

We specify a translog stochastic input distance function for empirical estimation. The translog stochastic input distance function for time $t$ is given by:

$$
\begin{aligned}
& \ln d(X, Y, t)=\alpha_{0}+\sum_{i=1}^{6} \alpha_{i} \ln X_{i}+\frac{1}{2} \sum_{i=1}^{6} \sum_{j=1}^{6} \alpha_{i j} \ln X_{i} \ln X_{j}+\sum_{k=1}^{3} \beta_{k} \ln Y_{k}+\frac{1}{2} \sum_{k=1}^{3} \sum_{l=1}^{3} \beta_{k l} \ln Y_{k} \ln Y_{l} \\
& +\sum_{i=1}^{6} \sum_{k=1}^{3} \tau_{i k} \ln X_{i} \ln Y_{k}+\kappa_{t} t+\kappa_{t t} t^{2}+\sum_{i=1}^{6} \kappa_{i t} t \ln X_{i}+\sum_{k=1}^{3} \kappa_{k t} t \ln Y_{k}
\end{aligned}
$$

where $X_{s}$ are inputs and $Y_{s}$ are outputs all presented in energy units. The six inputs used are: $X_{1}=$ energy from all machineries (i.e., power tiller for land preparation and shallow tube wells for irrigation), $X_{2}=$ energy from male labor input (family supplied + hired), $X_{3}=$ energy from female labor input (family supplied + hired), $X_{4}=$ energy from all type of feeds, $X_{5}=$ energy from all chemicals (fertilizers, pesticides and chemicals), and $X_{6}=$ energy from HYV rice seed and prawn and carp fingerlings. The three outputs are: $Y_{1}=$ energy produced by prawn, $Y_{2}=$ energy produced by carp, and $Y_{3}=$ energy produced by HYV rice and straw.

Justification of the choices of inputs are from the existing literature [6,7]. Women's involvement in agricultural production in Bangladesh has been increasing, although in the past they were believed to be involved only in the post-harvest processing of crops which underestimates their contribution to the sector [44]. Rahman [44] identified significant contribution of female labor input to agricultural productivity and efficiency. In fact, a substantial number of female labor was also used in addition to male labor in the gher farming system [6]. Therefore, following Rahman [44], we have included energy derived from female labor input separately to identify its independent influence on energy productivity.

In order to obtain the estimable form of the stochastic input distance function, we set $-\ln d=v-u$ and impose the restriction required for homogeneity of degree +1 in inputs 
$\left(\sum_{i=1}^{6} \alpha_{i}=1 ; \sum_{i=1}^{6} \alpha_{i j}=0 ; \sum_{i=1}^{6} \sum_{k=1}^{3} \gamma_{i k}=0 ; \sum_{i=1}^{3} \gamma_{k t}=0\right)$. This was done by normalizing the input vectors by any one input, specifically the energy input from all machineries $X_{1}$ [45]:

$$
\begin{aligned}
& -\ln X_{1}=\alpha_{0}+\sum_{i=2}^{5} \alpha_{i} \ln \left(\frac{X_{i}}{X_{1}}\right)+\frac{1}{2} \sum_{i=2}^{5} \sum_{j=2}^{5} \alpha_{i j} \ln \left(\frac{X_{i}}{X_{1}}\right) \ln \left(\frac{X_{j}}{X_{1}}\right)+\sum_{k=1}^{3} \beta_{k} \ln Y+\frac{1}{2} \sum_{k=1}^{3} \sum_{l=1}^{3} \beta_{k l} \ln Y_{k} \ln Y_{l} \\
& +\sum_{i=1}^{5} \sum_{k=1}^{3} \tau_{i k} \ln \left(\frac{X_{i}}{X_{1}}\right) \ln Y_{k}+\kappa_{t} t+\kappa_{t t} t^{2}+\sum_{i=1}^{5} \kappa_{i t} t \ln \left(\frac{X_{i}}{X_{1}}\right)+\sum_{k=1}^{3} \kappa_{k t} t \ln Y_{k}+v-u
\end{aligned}
$$

where the $v^{\prime}$ s are assumed to be Independently and Identically Distributed $\left(0, \sigma_{u}^{2}\right)$; and the $u^{\prime}$ s are technical efficiency effects assumed to be Identically Distributed such that $u$ is defined by the normal distribution truncated at zero with unknown mean and variance $\left(\mu, \sigma_{u}^{2}\right)$, defined by:

$$
\mu=\delta_{0}+\sum_{d=1}^{4} \delta_{d} Z_{d}
$$

where $Z_{1}=$ experience of the farmer (age in years); $Z_{2}=$ education of the farmer (years of completed schooling), $Z_{3}=$ household size (persons), and $Z_{4}=$ gher farm area (ha).

Justification of including these $Z$ variables to identify the determinants of technical (energy) efficiency of the gher farming system is based on the literature [6,15].

We replace the variance parameters, $\sigma_{v}^{2}$ and $\sigma_{u}^{2}$, with $\gamma=\frac{\sigma_{u}^{2}}{\left(\sigma_{v}^{2}+\sigma_{u}^{2}\right)}$ and $\sigma_{s}^{2}=\sigma_{v}^{2}+\sigma_{u}^{2}$ in the estimating model [46]. The input distances are predicted as: $d=E[\exp (u) \mid e]$, where $e=v-u$. The inverse of these input distances $(d)$ are the technical energy efficiency scores of each individual farm [47]. The Maximum Likelihood Estimation (MLE) method was used to estimate the parameters of the model (Coelli and Perelman, 1999). The model was estimated by STATA V-10 (Stata Corporation, College Station, TX, USA).

\section{Results and Discussion}

Table 2 presents summary statistics of the data used in this study. The mean gher area is 0.55 ha of which the HYV rice area is 0.34 ha. Among the inputs, feed input energy for prawn-carp enterprise is the highest followed by labor energy input for both enterprises. As a result, the mean energy input for prawn-carp enterprise is about 4.4 times higher than the mean energy input of HYV rice enterprise. In contrast, mean energy output of HYV rice enterprise is 18.2 times higher than the mean energy output of the prawn-carp enterprise (Table 2). The average age of the farmers is just over 43 years and education is above primary level. The average household size is 4.32 persons (Table 2).

Table 2. Summary statistics of the input-output and socio-economic factors of the gher farming system.

\begin{tabular}{cccc}
\hline Variables & Unit & Mean & Standard Deviation \\
\hline Gher area & ha & 0.55 & 0.43 \\
HYV rice area & ha & 0.34 & 0.28 \\
\hline Inputs & & & \\
\hline Feed & $\mathrm{MJ} \cdot \mathrm{ha}^{-1}$ & $47,795.33$ & $20,124.63$ \\
Chemicals & $\mathrm{MJ} \cdot \mathrm{ha}^{-1}$ & 6150.45 & 2562.13 \\
Labor & $\mathrm{MJ} \cdot \mathrm{ha}^{-1}$ & $18,288.87$ & 7085.77 \\
Machine & $\mathrm{MJ} \cdot \mathrm{ha}^{-1}$ & 4460.24 & 1784.82 \\
Seeds & $\mathrm{MJ} \cdot \mathrm{ha}^{-1}$ & 948.19 & 331.46 \\
Total gher Input & $\mathrm{MJ} \cdot \mathrm{ha}^{-1}$ & $77,643.07$ & $23,448.32$ \\
Total prawn-carp Input & $\mathrm{MJ} \cdot \mathrm{ha}^{-1}$ & $63,299.92$ & $23,104.30$ \\
Total HYV rice Input & $\mathrm{MJ} \cdot \mathrm{ha}^{-1}$ & $14,343.14$ & 3402.13 \\
\hline
\end{tabular}


Table 2. Cont.

\begin{tabular}{cccc}
\hline Variables & Unit & Mean & Standard Deviation \\
\hline Outputs & MJ.ha ${ }^{-1}$ & \\
\hline Gher output & MJ.ha ${ }^{-1}$ & $120,530.66$ & 6832.39 \\
Prawn-carp output & $\mathrm{MJ} \cdot \mathrm{ha}^{-1}$ & 6280.25 & 1300.85 \\
HYV rice output & $\mathrm{MJ} \cdot \mathrm{ha}^{-1}$ & $114,250.41$ & 6512.22 \\
\hline B. Socio-economic variables & & & \\
\hline Farmer's age & Years & 43.44 & 14.41 \\
Farmer's education & Completed years of schooling & 6.34 & 3.67 \\
Household size & Number & 4.23 & 1.01 \\
Number of observations & & 1260 & \\
\hline
\end{tabular}

\subsection{Changes in Energy Performance of the gher Farming System over Time}

The trend in total energy input and energy output per ha of the gher farming system is presented in Figure 1. A declining trend in energy input of the prawn-carp enterprise was observed during the later years, thereby leading to an overall decline in energy input use of the overall gher farming system over time. Table 3 presents results of the basic energy performance indicators of individual enterprises and the gher farming system as a whole and the average annual growth rate covering the period 2002-2015. Table 3 clearly shows that the prawn-fish enterprise is highly energy input intensive and produces very low level of energy outputs, also noted by Rahman and Barmon [6]. The apparent decline in performance measures are not statistically significant except energy productivity, which declined significantly albeit at a very low rate of $-0.005 \%$ p.a. The level of deficiency in net energy balance improved significantly over time at the rate of $1.30 \%$ p.a. (Table 3 ). The overall implication is that the prawn-carp enterprise on its own is not sustainable in the long run, which was also noted by Rahman and Barmon (2012).

In contrast, the HYV rice enterprise performs very well in terms of all energy performance measures, thereby generating very high level of energy outputs while using very low level of energy inputs, also noted by Rahman and Barmon [6]. This is because the inputs used for HYV Boro rice farming within a gher system are significantly lower. The unused feed supplied to the prawns/carps serve as fertilizers and the water retained within gher canals provides irrigation [6]. All the performance measures also improved significantly over time for the HYV rice enterprise. The use of energy input declined significantly at a high rate of $-1.30 \%$ p.a. whereas energy output increased significantly at the rate of $0.20 \%$ p.a. Consequently, specific energy improved significantly over time and net energy balance increased significantly at the rate of $0.40 \%$ p.a. (Table 3). The specific energy for HYV Boro rice in gher system is similar and/or higher from maize, wheat and all cereals $[7,48,49]$.

Consequently, evaluation of the gher farming as a whole passes the test of sustainability since all the performance measures improved significantly over time (Table 3). The mean net energy balance increased at the rate of $1.30 \%$ p.a. The main driver was the energy savings generated from the HYV rice enterprise, which is sufficient to offset the large energy deficit of the prawn-carp enterprise, also noted by Rahman and Barmon [6]. The net energy balance of the gher farming system estimated in this study is much higher than reported by Rahman and Barmon [6]. The joint influence of significantly increasing net energy balance of the HYV rice enterprise and significant reduction in deficiency in net energy balance of the prawn-carp enterprise over time contributed to increasing net energy balance of the gher farming system. 
Table 3. Energy performance of the gher farming system over time (mean values for selected year).

\begin{tabular}{|c|c|c|c|c|c|c|c|c|}
\hline Enterprises & Unit & 2002 & 2005 & 2008 & 2011 & 2013 & 2015 & Growth Rate, 2002-2015 (\%) \\
\hline \multicolumn{9}{|l|}{ Prawn and fish enterprise: } \\
\hline Energy input & $\mathrm{MJ} \cdot \mathrm{ha}^{-1}$ & $64,536.19$ & $64,430.67$ & $68,102.57$ & $62,381.54$ & $61,465.86$ & $58,421.40$ & -0.10 \\
\hline Energy output & MJ.ha ${ }^{-1}$ & 6379.39 & 6500.11 & 6172.23 & 6215.33 & 6172.90 & 6239.80 & -0.20 \\
\hline Specific energy & $\mathrm{MJ} \cdot \mathrm{kg}^{-1}$ & 46.82 & 44.65 & 50.01 & 45.11 & 45.02 & 42.09 & -0.10 \\
\hline Energy use efficiency & - & 0.11 & 0.11 & 0.10 & 0.11 & 0.11 & 0.12 & -0.10 \\
\hline Energy productivity & $\mathrm{kg} \cdot \mathrm{MJ}^{-1}$ & 0.23 & 0.23 & 0.23 & 0.23 & 0.23 & 0.22 & $-0.005^{*}$ \\
\hline Net energy & MJ $\cdot \mathrm{ha}^{-1}$ & $-58,156.80$ & $-57,930.56$ & $-61,930.33$ & $-56,166.22$ & $-55,292.96$ & $-52,181.60$ & $1.30^{* * *}$ \\
\hline \multicolumn{9}{|l|}{ HYV rice enterprise: } \\
\hline Energy input & $\mathrm{MJ} \cdot \mathrm{ha}^{-1}$ & $15,052.91$ & $14,984.36$ & $14,768.10$ & $14,418.84$ & $13,136.36$ & $12,344.27$ & $-1.30^{* * *}$ \\
\hline Energy output & $\mathrm{MJ} \cdot \mathrm{ha}^{-1}$ & $111,433.44$ & $115,639.56$ & $112,104.81$ & $115,511.31$ & $115,735.83$ & $115,555.49$ & $0.20 * * *$ \\
\hline Specific energy & $\mathrm{MJ} \cdot \mathrm{kg}^{-1}$ & 2.17 & 2.07 & 2.11 & 1.99 & 1.81 & 1.71 & $-1.50^{* * *}$ \\
\hline Energy use efficiency & - & 7.94 & 8.13 & 8.01 & 8.34 & 9.17 & 9.78 & $1.50 * * *$ \\
\hline Energy productivity & $\mathrm{kg} \cdot \mathrm{MJ}^{-1}$ & 0.50 & 0.51 & 0.51 & 0.52 & 0.58 & 0.61 & $1.50^{* * *}$ \\
\hline Net energy & MJ $\cdot \mathrm{ha}^{-1}$ & $96,380.53$ & $100,655.20$ & $97,336.71$ & $101,092.47$ & $102,599.47$ & $103,211.23$ & $0.40^{* * *}$ \\
\hline \multicolumn{9}{|l|}{ Gher system as a whole } \\
\hline Energy input & $\mathrm{MJ} \cdot \mathrm{ha}^{-1}$ & $79,589.10$ & $794,15.03$ & $82,870.66$ & $76,800.39$ & $74,602.22$ & $70,765.67$ & $-0.40 * *$ \\
\hline Energy output & $\mathrm{MJ} \cdot \mathrm{ha}^{-1}$ & $117,812.83$ & $122,139.67$ & $118,277.04$ & $121,726.64$ & $121,908.73$ & $121,795.30$ & $0.10^{* * *}$ \\
\hline Specific energy & $\mathrm{MJ} \cdot \mathrm{kg}^{-1}$ & 9.49 & 9.10 & 9.82 & 8.84 & 8.59 & 8.16 & $-0.50^{* * *}$ \\
\hline Energy use efficiency & - & 1.63 & 1.69 & 1.57 & 1.69 & 1.70 & 1.84 & $0.50^{* * *}$ \\
\hline Energy productivity & $\mathrm{kg} \cdot \mathrm{MJ}^{-1}$ & 0.18 & 0.19 & 0.17 & 0.19 & 0.19 & 0.20 & $0.40^{* *}$ \\
\hline Net energy & MJ $\cdot \mathrm{ha}^{-1}$ & $38,223.74$ & $42,724.64$ & $35,406.37$ & $44,926.25$ & $47,306.52$ & $51,029.63$ & $1.30 * * *$ \\
\hline
\end{tabular}

Note: All growth rates are computed using semi-logarithmic trend function: $\ln Y=\alpha+\beta T$, where $Y$ is the target variable, $T$ is time, $\ln$ is natural logarithm, and $\beta$ is the growth rate. ${ }^{* * *}$ significant at 1 percent level $(p<0.01)$; ${ }^{* *}$ significant at 5 percent level $(p<0.05) ;{ }^{*}$ significant at 10 percent level $(p<0.10)$.

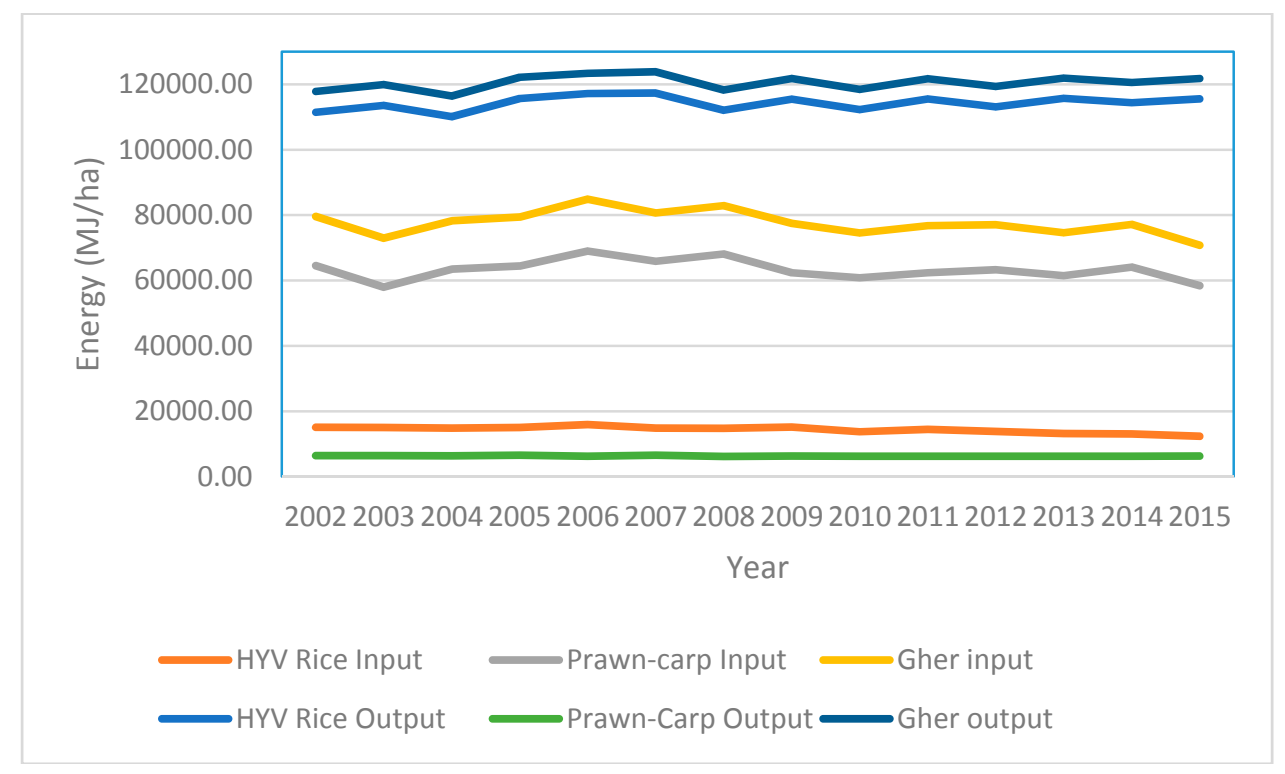

Figure 1. Trends in energy inputs and outputs of the gher farming system.

\subsection{Drivers of Energy Productivity of the gher Farming System}

First, a series of hypotheses tests were conducted to determine the choice of appropriate functional form, separability of inputs and outputs, scale economy, presence of inefficiency and the impact of time (Table 4). Next, the parameter estimates of the stochastic input distance function model using the maximum likelihood estimation (MLE) procedure is presented in Table 4. A generalized Likelihood Ratio (LR) test $\left(\mathrm{H}_{0}: \alpha_{k l}=\beta_{m n}=\tau_{k m}=0\right.$ for all $k, l, m$, and $\left.n\right)$ was conducted to choose between the restricted Cobb-Douglas versus flexible translog function, which was strongly rejected, thereby confirming that the latter is a better representation of the underlying production technology. Next, separability of inputs and outputs in the input distance function was tested by equating all the interaction terms between inputs and outputs to $0\left(\mathrm{H}_{0}\right.$ : all $\tau_{k m}=0$ for all $k$ and $\left.m\right)$ [40], which was strongly rejected $(p<0.01)$ implying that aggregating all inputs and outputs into a single index is not permitted. The existence of inefficiencies in the model was tested by examining the value 
of the parameter $\gamma$, which is the ratio of error variances from Equation (10) and lies between 0 and 1 . If $\gamma=0$, technical inefficiency is not present, and if $\gamma=1$, then there is no random noise. The value of $\gamma$ is estimated at 0.30 (see lower panel Table 5) which is low but significant $(p<0.10)$, thereby confirming that inefficiencies exist in the model. Next we tested whether the inefficiency effects variables used in the model are appropriate $\left(\mathrm{H}_{0}: \delta_{z}=0\right.$ for all $\left.z\right)$ which was strongly rejected $(p<0.01)$, implying that the inefficiency distributions vary across observations [40]. Finally, we tested the impact of time trend on productivity $\left(\mathrm{H}_{0}\right.$ : all $\kappa_{k}=0$ for all $\left.k\right)$ which was strongly rejected $(p<0.01)$, implying that productivity improved significantly over time (Table 4).

Table 4. Hypothesis tests.

\begin{tabular}{|c|c|c|c|c|c|}
\hline Name of test & $\begin{array}{l}\text { Parameter } \\
\text { Restrictions }\end{array}$ & $\begin{array}{l}\text { LR Test } \\
\text { Statistic }\end{array}$ & $\begin{array}{l}\text { Degrees of } \\
\text { Freedom }\end{array}$ & $\begin{array}{l}\chi^{2} \text { Critical } \\
\text { Value } 1 \%\end{array}$ & Outcome \\
\hline $\begin{array}{c}\text { Functional form test } \\
\text { (Translog vs. Cobb-Douglas) }\end{array}$ & $\begin{array}{c}\mathrm{H}_{0}: \alpha_{k l}=\beta_{m n}=\tau_{k m}=0 \\
\quad \text { for all } k, l, m, \text { and } n\end{array}$ & $558.80^{* * *}$ & 36 & 58.62 & Cobb-Douglas model is inadequate \\
\hline Input-output separability & $\begin{array}{l}\mathrm{H}_{0}: \text { all } \tau_{k m}=0 \\
\text { for all } k \text { and } m\end{array}$ & $160.12^{* * *}$ & 18 & 34.81 & $\begin{array}{l}\text { Aggregating output into a single } \\
\text { index will provide inconsistent result }\end{array}$ \\
\hline $\begin{array}{c}\text { Returns to scale } \\
\text { (Scale economy if } \varepsilon_{Y}<1 \text { ) }\end{array}$ & $\mathrm{H}_{0}:\left(\Sigma \beta_{m}\right)=1$ for all $m$ & $478.23 * * *$ & 1 & 6.64 & Significant scale economy exists \\
\hline No inefficiency effects & $\mathrm{H}_{0}: \delta_{z}=0$ for all $z$ & $174.33^{* * *}$ & 4 & 13.27 & $\begin{array}{l}\text { Inefficiencies are jointly explained } \\
\text { by these variables }\end{array}$ \\
\hline
\end{tabular}

More than seventy percent of the estimated coefficients are significantly different from zero at the $10 \%$ level of significance or higher (Table 5). All the variables except time are mean-differenced prior to estimation. Therefore, the first order coefficients can be read directly as elasticities of the distance function with respect to inputs and outputs evaluated at the sample means. However, for clarity of exposition, these are reproduced in Table 6. All the signs on the first order coefficients of inputs and outputs are theoretically consistent. For example, a positive sign on the coefficients of any input variable implies substitutability of that input with machinery. Similarly, a negative signs on the coefficient of any output variable implies that a reduction in the use of machinery will lead to a reduction in that output. The significantly different from zero coefficients on the interaction variables (second order terms) confirm that the production process is non-linear and that the choice of a flexible translog functional form is justified.

Table 5. Parameter estimates of the stochastic input distance function including inefficiency effects.

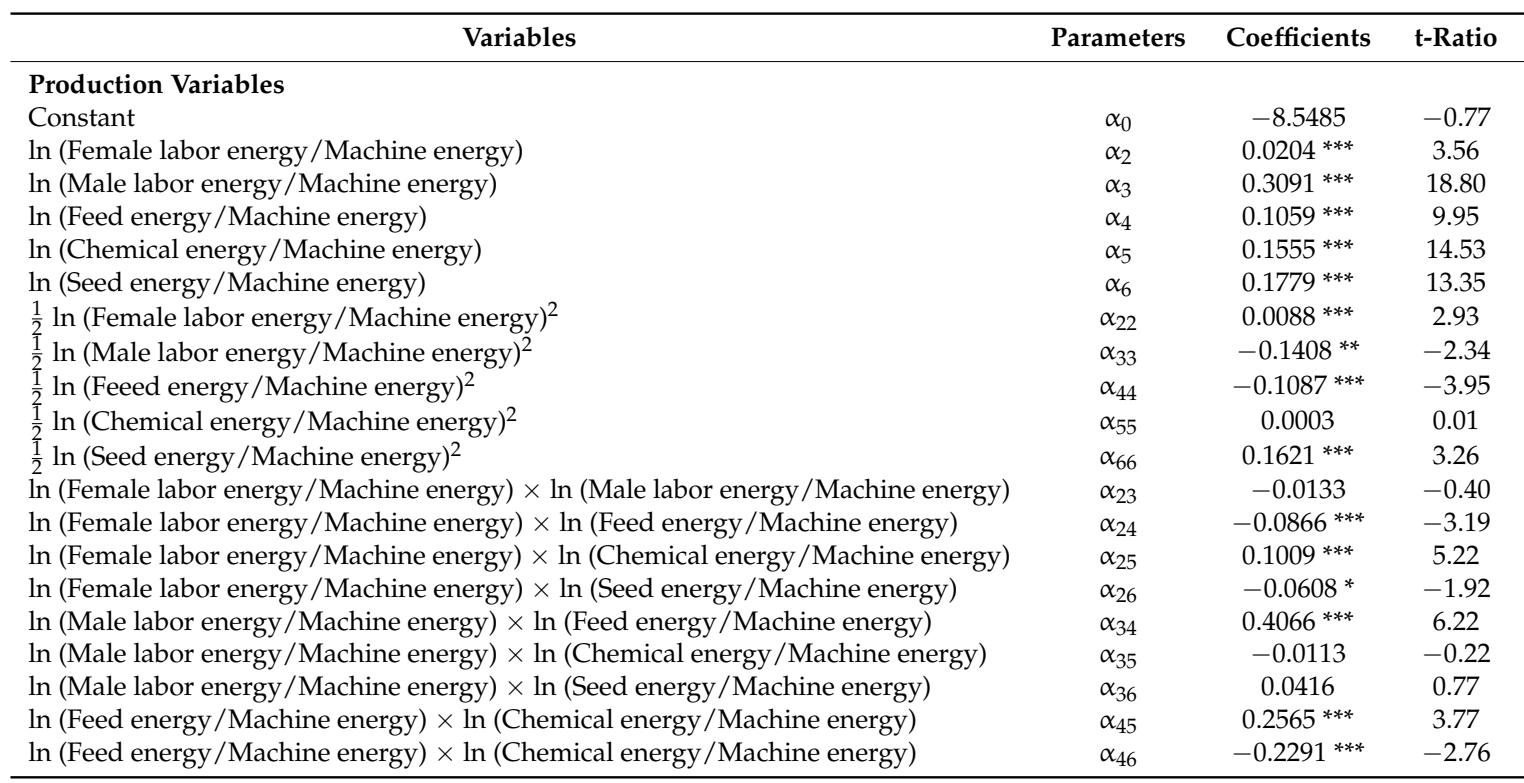


Table 5. Cont.

\begin{tabular}{|c|c|c|c|}
\hline Variables & Parameters & Coefficients & t-Ratio \\
\hline \multicolumn{4}{|l|}{ Production Variables } \\
\hline $\ln ($ Chemical energy /Machine energy) $\times \ln ($ Seed energy/Machine energy) & $\alpha_{56}$ & $-0.1597^{* * *}$ & -2.54 \\
\hline $\ln$ (Rice energy) & $\beta_{1}$ & $-0.2641^{* * *}$ & -3.56 \\
\hline $\ln$ (Prawn energy) & $\beta_{2}$ & $-0.3159 * * *$ & -11.78 \\
\hline $\ln ($ Carp energy) & $\beta_{3}$ & $-0.0756^{* * *}$ & -10.12 \\
\hline$\frac{1}{2} \ln (\text { Rice energy) })^{2}$ & $\beta_{11}$ & $-5.2921^{* * *}$ & -3.61 \\
\hline$\frac{1}{2} \ln (\text { Prawn energy })^{2}$ & $\beta_{22}$ & -0.0665 & -0.78 \\
\hline$\frac{1}{2} \ln (\text { Carp energy })^{2}$ & $\beta_{33}$ & 0.0305 & 1.71 \\
\hline $\ln ($ Rice energy) $\times \ln$ (Prawn energy) & $\beta_{12}$ & $-2.0371^{* *}$ & -2.27 \\
\hline $\ln ($ Rice energy) $\times \ln ($ Carp energy $)$ & $\beta_{13}$ & -0.0860 & -0.35 \\
\hline $\ln ($ Prawn energy) $\times \ln ($ Carp energy) & $\beta_{23}$ & $-0.2505^{* * *}$ & -2.83 \\
\hline $\ln$ (Female labor energy/Machine energy) × ln (Rice energy) & $\tau_{21}$ & -0.0962 & -1.11 \\
\hline $\ln ($ Female labor energy /Machine energy) $\times \ln$ (Prawn energy) & $\tau_{22}$ & $0.1685^{* * *}$ & 4.54 \\
\hline $\ln ($ Female labor energy /Machine energy) $\times \ln ($ Carp energy) & $\tau_{23}$ & $-0.0419^{* * *}$ & -4.47 \\
\hline $\ln ($ Male labor energy/Machine energy) $\times \ln ($ Rice energy) & $\tau_{31}$ & $0.8651^{* * *}$ & 3.64 \\
\hline $\ln$ (Male labor energy/Machine energy) $\times \ln$ (Prawn energy) & $\tau_{32}$ & 0.1224 & 1.35 \\
\hline $\ln ($ Male labor energy/Machine energy) $\times \ln ($ Carp energy) & $\tau_{33}$ & $-0.1289 * * *$ & -5.20 \\
\hline $\ln ($ Feed energy /Machine energy) $\times \ln$ (Rice energy) & $\tau_{41}$ & 0.0968 & 0.60 \\
\hline $\ln ($ Feed energy $/$ Machine energy) $\times \ln$ (Prawn energy) & $\tau_{42}$ & $-0.1296 * *$ & -1.99 \\
\hline $\ln$ (Feed energy/Machine energy) $\times \ln$ (Carp energy) & $\tau_{43}$ & 0.0200 & 1.12 \\
\hline $\ln ($ Chemical energy /Machine energy) × $\ln$ (Rice energy) & $\tau_{51}$ & 0.1157 & 0.63 \\
\hline $\ln ($ Chemical energy/Machine energy) $\times \ln ($ Prawn energy) & $\tau_{52}$ & -0.0920 & -1.27 \\
\hline $\ln ($ Chemical energy/Machine energy) $\times \ln ($ Carp energy) & $\tau_{53}$ & $0.0541^{* * *}$ & 2.90 \\
\hline $\ln ($ Seed energy /Machine energy) $\times \ln$ (Rice energy) & $\tau_{61}$ & $-0.9501^{* * *}$ & -4.18 \\
\hline $\ln ($ Seed energy $/$ Machine energy) $\times \ln$ (Prawn energy) & $\tau_{62}$ & $-0.2477^{* * *}$ & -2.87 \\
\hline $\ln$ (Seed energy/Machine energy) × $\ln$ (Carp energy) & $\tau_{63}$ & $0.0930^{* * *}$ & 4.03 \\
\hline \multicolumn{4}{|l|}{ Time trend and interactions } \\
\hline Time & $\mathrm{K}_{1}$ & $0.0138^{* * *}$ & 12.09 \\
\hline$\frac{1}{2}(\text { Time })^{2}$ & $\kappa_{11}$ & $0.0021 * * *$ & 3.71 \\
\hline Time $\times \ln ($ Female labor energy / Machine energy) & $\mathrm{K}_{12}$ & $-0.0026^{* *}$ & -2.22 \\
\hline Time $\times \ln ($ Male labor energy/Machine energy) & $\mathrm{K}_{13}$ & $-0.0228 * * *$ & -6.28 \\
\hline Time $\times \ln ($ Feed energy/Machine energy) & $\kappa_{14}$ & 0.0015 & 0.58 \\
\hline Time $\times \ln$ (Chemical energy/Machine energy) & $\kappa_{15}$ & -0.0001 & -0.05 \\
\hline Time $\times \ln ($ Seed energy /Machine energy) & $\kappa_{16}$ & $0.0167^{* * *}$ & 4.65 \\
\hline Time $\times \ln ($ Rice energy) & $\kappa_{17}$ & $-0.0514^{* * *}$ & -2.68 \\
\hline Time $\times \ln$ (Prawn energy) & $\mathrm{K}_{18}$ & 0.0050 & 0.76 \\
\hline Time $\times \ln ($ Carp energy) & $\mathrm{K}_{19}$ & $0.0074^{* * *}$ & 4.09 \\
\hline \multicolumn{4}{|l|}{ Model diagnostics } \\
\hline Gamma & $\gamma$ & $0.3007 *$ & 1.78 \\
\hline Sigma-squared & $\sigma_{\mathrm{s}}^{2}$ & $0.0151^{* * *}$ & 25.08 \\
\hline Log likelihood & & 855.6781 & \\
\hline$\chi_{(54,0.99)}^{2}$ & & $19,016.51^{* * *}$ & \\
\hline \multicolumn{4}{|l|}{ Inefficiency effects function } \\
\hline Constant & $\delta_{0}$ & 0.2053 & 0.02 \\
\hline Experience & $\delta_{1}$ & $-0.0018^{* * *}$ & -5.92 \\
\hline Education & $\delta_{2}$ & $-0.0061^{* * *}$ & -5.32 \\
\hline Household size & $\delta_{3}$ & $0.0131 * * *$ & 3.27 \\
\hline Gher area & $\delta_{4}$ & $0.1697 * * *$ & 11.55 \\
\hline Number of total observations & $\mathrm{N}$ & 1260 & \\
\hline
\end{tabular}

Note: ${ }^{* *}$ significant at 1 percent level $(p<0.01) ;{ }^{* *}$ significant at 5 percent level $(p<0.05) ;{ }^{*}$ significant at 10 percent level $(p<0.10)$.

The scale elasticity $\varepsilon_{Y}$ provides an overall measure of the incentive to increase operation size of multiple enterprises. The estimate of $\varepsilon_{Y}=-0.66$ suggests presence of significant scale economies (Table 6). Rahman [44,50] also noted that increasing returns to scale exist for the diversified crop production system in Bangladesh but Rahman and Kazal [7] noted that constant returns to scale exists instead. Table 6 shows that output elasticities of all enterprises are significant $(p<0.01)$, implying that increasing production of any of these outputs will significantly increase energy use. The highest energy elasticity is for prawn output indicating that a $1 \%$ increase in prawn output will increase the use of energy by $0.32 \%$. Rahman and Barmon [6] also noted highest prawn output elasticity of -0.22 . Rice energy output elasticity is also substantially high, estimated at -0.26 . This value is much higher 
than the output energy elasticity of cereals at -0.14 (i.e., rice, wheat and maize combined) reported by Rahman and Kazal [7].

Table 6. Output jointness, input and output elasticites.

\begin{tabular}{|c|c|c|c|}
\hline Variables & Symbol & Value & t-Ratio \\
\hline \multicolumn{4}{|l|}{ Output energy elasticities } \\
\hline Scale economy & $\varepsilon_{Y}$ & $-0.6556^{* * *}$ & - \\
\hline Rice energy & $\varepsilon_{Y 1}$ & $-0.2641^{* * *}$ & -3.56 \\
\hline Prawn energy & $\varepsilon_{Y 2}$ & $-0.3159^{* * *}$ & -11.78 \\
\hline Carp energy & $\varepsilon_{Y 3}$ & $-0.0756^{* * *}$ & -10.12 \\
\hline \multicolumn{4}{|l|}{ Input energy elasticities } \\
\hline Female labor energy & $\varepsilon_{X 2}$ & $0.0204^{* * *}$ & 3.56 \\
\hline Male labor energy & $\varepsilon_{X 3}$ & $0.3091^{* * *}$ & 18.80 \\
\hline Feed energy & $\varepsilon_{X 4}$ & $0.1059 * * *$ & 9.95 \\
\hline Chemical energy & $\varepsilon_{X 5}$ & $0.1555^{* * *}$ & 14.53 \\
\hline Seed energy & $\varepsilon_{X 6}$ & $0.1779 * * *$ & 13.35 \\
\hline Machine energy & $\varepsilon_{X 1}$ & 0.2312 & - \\
\hline \multicolumn{4}{|l|}{$\begin{array}{l}\text { Output jointness or } \\
\text { complementarity }\end{array}$} \\
\hline Rice energy $\times$ Prawn energy & $\varepsilon_{Y 12}$ & $-2.0371 * *$ & -2.27 \\
\hline Rice energy $\times$ Carp energy & $\varepsilon_{Y 13}$ & -0.0860 & -0.35 \\
\hline Prawn energy $\times$ Carp energy & $\varepsilon_{Y 23}$ & $-0.2505^{* * *}$ & -2.83 \\
\hline
\end{tabular}

Similarly, the input energy elasticities reflect the relative importance of inputs in production. Table 6 reveals that all five inputs contribute significantly to the production process. The elasticity with respect to male labor is the largest, implying that energy from male labor represents $0.31 \%$ of total energy use at the sample mean for the overall gher farming system. Energy from female labor, although significant, accounts for only $0.02 \%$ of total energy use. Chemical energy also accounts for a substantial $0.16 \%$ of total energy use. Energy elasticity of machineries, which was computed as a residual, is also substantial, estimated at 0.23 (Table 6). The renewable energy component of the system (i.e., sum of energy inputs from male and female labor, seeds and feeds) is estimated at $61 \%$, which is substantial.

The cross-effects, i.e., second order coefficients $\left(\beta_{k l}\right)$, provides information on the output jointness or complementarities. This information is reproduced in the mid-panel of Table 6. Results show that the prawn and rice enterprise as well as prawn and carp enterprise combinations are negative and significant $(p<0.05)$, implying competitive relationship in gher farming system. In contrast, Rahman and Barmon [6] noted significant output jointness/complementarity between rice and prawn enterprise in gher farming. Rahman and Kazal [7] also noted output jointness between cereal and oilseed enterprises but competitive relationship between pulse and jute as well as oilseed and jute enterprise combinations in Bangladesh.

\subsection{Total Factor Energy Productivity Change and Sources of Growth}

The parameter estimates of the time $t$ and its interaction with input and output variables in the stochastic input distance function (Table 6) are used to compute technical change (TC) indices of the gher farming system. The estimated technical energy efficiency scores, which are the inverse of the input distances $d$, are used to compute technical energy efficiency change (EEC) indices. Then the Malmquist Total factor energy Productivity (TFEP) indices were computed as a product of TC and EEC for the gher farming system for each individual farm over the 14-year period (2002-2015).

The coefficient on the time variable $t$ is significantly positive implying that the gher farming system has experienced significant technological progress at the rate of $1.4 \%$ p.a. which is highly encouraging 
(Table 5). The first column in Table 7 presents technical energy efficiency scores, which show that overall mean technical energy efficiency (MTE) grew at a low rate of $0.19 \%$ p.a. These figures indicate that there are substantial scope to increase MTE of the gher farmers. Rahman and Barmon [6] noted a higher level of MTE of 0.92 .

Table 7. Total factor energy productivity and its components of the gher farming system, (2002-2015).

\begin{tabular}{ccccc}
\hline Year & $\begin{array}{c}\text { Energy Efficiency } \\
\text { Scores (MTE) }\end{array}$ & $\begin{array}{c}\text { Technical Change } \\
\text { (TC) }\end{array}$ & $\begin{array}{c}\text { Energy Efficiency } \\
\text { Change (EEC) }\end{array}$ & $\begin{array}{c}\text { Total Factor Energy } \\
\text { Productivity (TFEP) }\end{array}$ \\
\hline 2002 & 0.7797 & 1.0000 & 1.0000 & 1.0000 \\
2003 & 0.7803 & 1.3051 & 1.0007 & 1.3061 \\
2004 & 0.7803 & 1.3134 & 1.0024 & 1.3165 \\
2005 & 0.7841 & 1.3149 & 1.0024 & 1.3180 \\
2006 & 0.7896 & 1.3261 & 1.0070 & 1.3354 \\
2007 & 0.7897 & 1.3405 & 1.0001 & 1.3407 \\
2008 & 0.7888 & 1.3481 & 0.9988 & 1.3466 \\
2009 & 0.7900 & 1.3468 & 1.0016 & 1.3489 \\
2010 & 0.7923 & 1.3483 & 1.0029 & 1.3522 \\
2011 & 0.7948 & 1.3520 & 1.0032 & 1.3563 \\
2012 & 0.7952 & 1.3514 & 1.0005 & 1.3520 \\
2013 & 0.7950 & 1.3459 & 0.9998 & 1.3456 \\
2014 & 0.8000 & 1.3301 & 1.0063 & 1.3384 \\
2015 & 0.7992 & 1.3431 & 0.9989 & 1.3417 \\
Geometric mean & 0.7899 & 1.3084 & 1.0018 & 1.3107 \\
Growth rate $(\%)$ & 0.1905 & 2.5700 & -0.0075 & 2.5620 \\
\hline
\end{tabular}

The results of the inefficiency effects function, which provide information on the drivers of technical energy efficiency of the gher farming system is presented at the lower panel of Table 5. The results show that experience (i.e., farmer's age) and education significantly increase energy efficiency whereas household size and gher area significantly reduces energy efficiency. These findings are in contrast with Rahman and Kazal [7] who noted that household size increases energy efficiency in a diversified farming system and Rahman and Barmon [6] noted that the gher area significantly increases energy efficiency. Asadullah and Rahman [51] noted significant influence of education of technical efficiency of rice production in Bangladesh.

It is highly encouraging to note that the Total factor energy Productivity (TFEP) of the gher farming system increased at the rate of $2.56 \%$ p.a. mainly driven by technical progress (TC) at the rate of $2.57 \%$ p.a. with a negligible decline in energy efficiency change (EEC) at the rate of $-0.008 \%$ p.a. (Table 7). This rate of growth in TFEP is much higher than the total factor productivity growth reported for Bangladesh agriculture increasing at the rate of $0.57 \%$ p.a. [52] and elsewhere in the developing economies, e.g., commercial agricultural sector in Botswana at the rate of $1.16 \%$ p.a. [40]. This finding provides evidence that the gher farming system is sustainable in terms of energy use and reinforces the findings observed in Table 3.

\section{Conclusions and Policy Implications}

The principal aims of this study were to evaluate trends in basic energy performance measures over time and to compute TFEP, TC and EEC indices of the gher farming system, which is operating in the coastal regions of Bangladesh, by utilizing a unique farm-level panel data of a cohort of 90 farmers covering a 14-year period (2002-2015). The purpose is to judge whether the gher farming system is sustainable over time when evaluated in terms of energy use. Results reveal that although the prawn-carp enterprise is highly inefficient in energy use, the high-energy efficient HYV rice enterprise offset the negative net energy balance of the former and makes the gher farming system as a whole energy efficient. However, substantial scope remains for improving the technical energy efficiency of gher farmers. Experience and education are the significant drivers of energy efficiency. 
The TFEP grew at the rate of $2.56 \%$ p.a. mainly driven by TC at the rate of $2.57 \%$ p.a. with negligible decline in EEC.

The key conclusion that emerges from this study is that the gher farming system demonstrated significant productivity growth driven by technical progress over time and, therefore, it is sustainable in the long-run when evaluated in terms of energy use. Gher farmers are becoming more prudent in the use of their input levels, particularly in the HYV rice enterprise, which had a dominant influence in improving net energy balance, thereby, leading to significantly improved performance of the gher farming system as a whole over time. Also significant increase in energy output of the HYV rice enterprise over time further contributed to overall sustainability of the gher farming system. An estimated $61 \%$ of total energy inputs are renewable, which is encouraging.

The following policy implications can be drawn from this study. First, a major thrust should be geared towards maintaining and/or improving productivity of the HYV rice enterprise. This can be achieved through R\&D investment. The Bangladesh Rice Research Institute (BRRI) has a major role to play in this area to develop strains of HYV rice that are particularly suited to gher farming system. Second, measures should be undertaken to improve performance of the prawn enterprise through developing feed ingredients and production technologies. This is because the prawn enterprise seem to be stagnant in energy performance over time. The Bangladesh Fisheries Research Institute (BFRI) has an important role to play in this regard. Third, investment in education targeted at the gher farmers will significantly improve energy efficiency. An effective implementation of these policy measures will boost the sector and enable to sustain it in the long-run.

Author Contributions: S.R. analyzed the data, fitted the model and wrote the article. B.K.B. collected the data, recorded and processed the data into digital format (i.e., MS Excel).

Funding: This research received no external funding.

Acknowledgments: The authors gratefully acknowledge the comments of three anonymous reviewers and the editor for constructive and critical comments that have substantially improved this paper. All caveats remain with the authors.

Conflicts of Interest: The authors declare no conflict of interest.

\section{References}

1. Pimentel, D. Energy Inputs in Food Crop Production in Developing and Developed Nations. Energies 2009, 2,1-24. [CrossRef]

2. IEA. International Energy Annual. World Energy Overview. 2007. Available online: http://www/e/ia/doe. gov/iea/overview.html (accessed on 15 May 2008).

3. PRB. World Population Data Sheet; Population Reference Bureau: Washington, DC, USA, 2008.

4. Scott, G.J.; Rosegrant, M.W.; Ringler, M.W. Roots and Tubers for the 21st Century: Trends, Projections and Policy Options. In Food, Agriculture and the Environment Discussion Paper 31; International Food Policy Research Institute: Washing, DC, USA, 2000.

5. Khosruzzaman, S.; Asgar, M.; Rehman, K.M.R.; Akbar, S. Energy intensity and productivity in relation to agriculture: Bangladesh perspective. J. Bangladesh Acad. Sci. 2010, 34, 59-70. [CrossRef]

6. Rahman, S.; Barmon, B.K. Energy productivity and efficiency of the gher (prawn-fish-rice) farming system in Bangladesh. Energy 2012, 43, 293-300. [CrossRef]

7. Rahman, S.; Kazal, M.M.H. Whether crop diversification is energy efficient: An empirical analysis from Bangladesh. Renew. Sustain. Energy Rev. 2015, 45, 745-754. [CrossRef]

8. FRSS. Yearbook of Fisheries Statistics of Bangladesh; Fisheries Resources Survey System (FRSS), Department of Fisheries: Dhaka, Bangladesh, 2017; Volume 33, 124p.

9. New, M.B. History and global status of freshwater prawn farming. In Freshwater Prawns: Biology and Farming; New, M.B., Valenti, W.C., Tidwell, J.H., D’Abramo, L.R., Kutty, M.N., Eds.; Wiley-Blackwell: Oxford, UK, 2010; pp. 1-11.

10. FAO. Fishstat Journal; Version 2.11.4; FAO: Rome, Italy, 2015.

11. Das, D.N. Fish farming in rice environments of North Eastern India. Aquac. Asia 2002, 7, $43-47$. 
12. Galib, S.M. Integrated fish-farming: Rice-fish. In BD Fish; Available online: http://en.bdfish.org/2010/10/ integrated-fish-farming-rice-fish/2010 (accessed on 1 November 2013).

13. Ahmed, N.; Allison, E.H.; Muir, J.F. Rice fields to prawn farms: A blue revolution in Southwest Bangladesh? Aquac. Int. 2010, 18, 555-574. [CrossRef]

14. Ahmed, N.; Bunting, S.W.; Rahman, S.; Garforth, C.J. Community-based climate change adaptation strategies for integrated prawn-fish-rice farming in Bangladesh to promote social-ecological resilience. Rev. Aquac. 2014, 6, 20-35. [CrossRef]

15. Rahman, S.; Barmon, B.K.; Ahmed, N. Diversification economies and efficiencies in a 'Blue-Green Revolution' combination: A case study of prawn-fish-rice farming in the gher system in Bangladesh. Aquac. Int. 2011, 19, 665-682. [CrossRef]

16. DoF. National Fish Week 2012 Compendium (in Bengali); Department of Fisheries: Dhaka, Bangladesh, 2012.

17. Ahmed, N.; Flaherty, M.S. Opportunities and challenges for the development of prawn farming with fish and rice in southeast Bangladesh: Potential for food security and economic growth. Food Secur. 2013, 5, 637-649. [CrossRef]

18. Kendrick, A. The gher Revolution: The Social Impacts of Technological Change in Freshwater Prawn Cultivation in Southern Bangladesh; Bangladesh Aquaculture and Fisheries Resource Unit: Dhaka, Bangladesh, 1994.

19. Ito, S. Globalization and agrarian change: A case of freshwater prawn farming in Bangladesh. J. Int. Dev. 2004, 16, 1003-1013. [CrossRef]

20. Movik, S.; Mehta, L.; Mtisi, S.; Nicol, A. A blue revolution for African agriculture? Int. Dev. Stud. Bull. 2005, 36, 41-45. [CrossRef]

21. Ahmed, N.; Brown, J.H.; Muir, J.F. Freshwater prawn farming in gher systems in southwest Bangladesh. Aquac. Econ. Manag. 2008, 12, 207-223. [CrossRef]

22. Barmon, B.K.; Kondo, T.; Osanami, F. Water productivity of HYV variety of paddy production: Rice-prawn and year-round paddy farming systems in Bangladesh. Asia-Pac. J. Rural. Dev. 2008, 18, $99-118$.

23. Shaifee, S.; Topal, E. When will fossil fuel reserves be diminished? Energy Policy 2009, 37, 181-189. [CrossRef]

24. Sabiha, N.-E.; Salim, S.; Rahman, S.; Rola-Rubzen, M.F. Measuring environmental sustainability in agriculture: A composite environmental impact index approach. J. Environ. Manag. 2016, 166, 84-93. [CrossRef]

25. Hayati, D.; Ranjbar, Z.; Karami, E. Measuring Agricultural Sustainability. Available online: https:// www. springer.com/gb/book/9789048195121 (accessed on 5 December 2018).

26. Huang, H.; Wang, T. The Total-Factor Energy Efficiency of Regions in China: Based on Three-Stage SBM Model. Sustainability 2017, 9, 1664. [CrossRef]

27. Chang, M.-C. A comment on the calculation of the total-factor energy efficiency (TFEE) index. Energy Policy 2013, 53, 500-504. [CrossRef]

28. Marques, H.L.A.; New, M.B.; Boock, M.V.; Barros, H.P.; Mallasen, M.; Valenti, W.C. Integrated Freshwater Prawn Farming: State-of-the-Art and Future Potential. Rev. Fish. Sci. Aquac. 2016, 24, 264-293. [CrossRef]

29. Zhang, X.-P.; Cheng, X.-M.; Yuan, J.-H.; Gao, X.-J. Total-factor energy efficiency in developing countries. Energy Policy 2011, 39, 644-650. [CrossRef]

30. Chang, T.-P.; Hu, J.-L. Total-factor energy productivity growth, technical progress, and efficiency change: An empirical study of China. Appl. Energy 2010, 87, 3262-3270. [CrossRef]

31. Honma, S.; Hu, J.-L. Total-factor energy productivity growth of regions in Japan. Energy Policy 2009, 37, $3941-3950$. [CrossRef]

32. Hu, J.-L.; Wang, S.-C. Total-factor energy efficiency of regions in China. Energy Policy 2006, 34, $3206-3217$. [CrossRef]

33. Mukherjee, A.N.; Kuroda, Y. Productivity growth in Indian agriculture: Is there evidence of convergence across states? Agric. Econ. 2003, 29, 43-53. [CrossRef]

34. Fan, S.; Hazell, P.; Thorat, S. Government spending, growth and poverty in rural India. Am. J. Agric. Econ. 2000, 82, 1038-1051. [CrossRef]

35. Mohammadi, A.; Tabatabaeefar, A.; Shahin, S.; Rafiee, S.; Keyhani, A. Energy use and economical analysis of potato production in Iran a case study: Ardabil province. Energy Convers. Manag. 2008, 49, 3566-3570. [CrossRef]

36. Banaeian, N.; Zangeneh, M. Study on energy efficiency in corn production of Iran. Energy 2011, 36, 5394-5402. [CrossRef] 
37. Canakci, M.; Topakci, M.; Akinci, I.; Ozmerzi, A. Energy use pattern of some field crops and vegetable production: Case study for Antalya Region, Turkey. Energy Convers. Manag. 2005, 46, 655-666. [CrossRef]

38. Quabili, W.; International Food Policy Research Institute, Washington, DC, USA. Personal communication, 2009.

39. Kumbhakar, S.S.; Orea, L.; Rodriguez-Alvarez, A.; Tsonias, E.G. Do we estimate an input or an output distance function? An application of the mixed approach to European railways. J. Prod. Anal. 2007, 27, 87-100. [CrossRef]

40. Irz, X.; Thirtle, C. Dual Technological Development in Botswana Agriculture: A Stochastic Input Distance Function Approach. J. Agric. Econ. 2004, 55, 455-478. [CrossRef]

41. Morrison-Paul, C.J.; Nehring, R. Product diversification, production systems, and economic performance in U.S. agricultural production. J. Econom. 2005, 126, 525-548. [CrossRef]

42. Färe, R.; Primont, D. Multi-output Production and Duality: Theory and Applications; Kluwer Academic Publishers: Boston, MA, USA, 1995.

43. Morrison-Paul, C.J.; Johnston, W.E.; Frengley, G.A.G. Efficiency in New Zealand Sheep and Beef Farming: The Impacts of Regulatory Reform. Rev. Econ. Stat. 2000, 82, 325-337. [CrossRef]

44. Rahman, S. Women's labor contribution to productivity and efficiency: Empirical evidence from Bangladesh. J. Agric. Econ. 2010, 61, 318-342. [CrossRef]

45. Battese, G.E.; Corra, G.S. Estimation of a production frontier model: With application to the pastoral zone of Eastern Australia. Aust. J. Agric. Econ. 1977, 21, 161-179. [CrossRef]

46. Coelli, T.J.; Perelman, S. A comparison of parametric and non-parametric distance functions: With application to European railways. Eur. J. Oper. Res. 1999, 117, 326-339. [CrossRef]

47. Coelli, T.J.; Fleming, E. Diversification economies and specialization efficiencies in a mixed food and coffee smallholder farming system in Papua New Guinea. Agric. Econ. 2004, 31, 229-239. [CrossRef]

48. Rahman, S.; Hasan, M.K. Energy productivity and efficiency of wheat farming in Bangladesh. Energy 2014, 66, 107-114. [CrossRef]

49. Rahman, S.; Rahman, M.S. Energy productivity and efficiency of maize accounting for the choice of growing season and environmental factors: An empirical analysis from Bangladesh. Energy 2013, 49, 329-336. [CrossRef]

50. Rahman, S. Whether crop diversification is a desired strategy for agricultural growth in Bangladesh. Food Policy 2009, 34, 340-349. [CrossRef]

51. Asadullah, M.N.; Rahman, S. Farm productivity and efficiency in rural Bangladesh: The role of education revisited. Appl. Econ. 2009, 41, 17-33. [CrossRef]

52. Rahman, S.; Salim, R. Six decades of total factor productivity change and sources of growth in Bangladesh agriculture (1948-2008). J. Agric. Econ. 2013, 63, 275-294. [CrossRef] 